Check for updates

London

Cite this as: BMJ 2021;374:n1760 http://dx.doi.org/10.1136/bmi.n1760 Published: 09 July 2021

\section{Covid-19: Free rapid testing may end once most adults are fully vaccinated}

\author{
Ingrid Torjesen
}

Free lateral flow tests will be available until the end of August, but it has yet to be determined whether they will continue to have a role once most adults are fully vaccinated, the head of the agency responsible for health protection in the UK has said.

Currently, all adults and secondary school pupils are encouraged to use the rapid tests on themselves at home twice a week. Although not as accurate as polymerase chain reaction tests, lateral flow devices are able to pick up some asymptomatic cases and potentially those that are most infectious, as they detect cases with the highest viral loads. ${ }^{12}$

Jenny Harries, chief executive of the UK Health Security Agency, which recently took over the responsibilities of Public Health England and NHS Test and Trace, said that the free tests would be available for adults until at least the end of August and for schoolchildren until at least the end of September.

Giving evidence on 8 July to a House of Commons Public Accounts Committee inquiry into NHS Test and Trace, Harries was asked to comment on media reports that the public would then be expected to pay for the tests from the end of August. She replied, "Nobody has discussed charging." But she added that, rather than it being an issue of cost, the role of the rapid tests was being reviewed in terms of whether they would be an "effective and essential health intervention going forward," with most of the population vaccinated, implying that they may have a more limited role.

"We have been using lateral devices predominantly in an unvaccinated population. Obviously, that's changing now," Harries said. Fully vaccinated individuals "may still be able to transmit infection, but fewer people will," she added. "You may have lower viral loads, so I think there's a lot of scientific elements behind this that we need to take into consideration."

Chris Wormald, permanent secretary at the Department of Health and Social Care for England, also giving evidence, said, "Let's be absolutely clear on this point. What we are doing is looking at what the public health case is for use going forward."

Several studies have found reduced viral loads after vaccination in people who have been vaccinated with the mRNA covid-19 vaccines (Pfizer-BioNTech or Moderna) or the Oxford-AstraZeneca vaccine, ${ }^{3-5}$ and researchers at the University of Birmingham found that false negative results from lateral flow device tests were more likely in people with lower viral loads. ${ }^{6}$
A recent damning report on the NHS Test and Trace system from the National Audit Office found that just 96 million (14\%) of the 691 million lateral flow device test kits distributed had been registered as used. ${ }^{7}$

"If you actually take out the numbers of tests which we know are, if you'd like, in transit or in store that figure rises to 20\%," Harries said. "But surveys suggest that more than $40 \%$ of people are using the tests.”

Dido Harding, the former head of NHS Test and Trace, said it was "completely understandable" that some people were performing tests but not registering the results if they were negative, so a lot of work was being done to "communicate why [NHS Test and Trace] need to know, regardless of whether the result is positive or negative, that you've done the test."

Torjesen I. Covid-19: How the UK is using lateral flow tests in the pandemic. BMJ 2021;372:n287. doi: 10.1136/bmj.n287 pmid: 33541908

2 Key points summary: asymptomatic testing for SARS-CoV-2 using antigen-detecting lateral flow devices (evidence from performance data October 2020 to May 2021). 7 Jul 2021. https://www.gov.uk/government/publications/lateral-flow-device-performance-data/key-points-summary-asymptomatic-testing-for-sars-cov-2-using-antigen-detecting-lateralflow-devices-evidence-from-performance-data-october-2020-to-m.

3 Thompson MG, Burgess JL, Naleway AL, etal. Prevention and attenuation of covid-19 with the BNT162b2 and mRNA-1273 Vaccines. N Engl J Med 2021;(Jun). doi: 10.1056/NEJMoa2107058. pmid: 34192428

4 Levine-Tiefenbrun M, Yelin I, Katz R, etal. Initial report of decreased SARS-CoV-2 viral load after inoculation with the BNT162b2 vaccine. Nat Med 2021;27:790-2. doi: 10.1038/s41591-021-01316-7. pmid: 33782619

5 Emary KRW, Golubchik T, Aley PK, etalCOVID-19 Genomics UK consortiumAMPHEUS ProjectOxford COVID-19 Vaccine Trial Group. Efficacy of ChAdOx1 nCoV-19 (AZD1222) vaccine against SARS-CoV-2 variant of concern 202012/01 (B.1.1.7): an exploratory analysis of a randomised controlled trial. Lancet 2021;397:1351-62. doi: 10.1016/S0140-6736(21)00628-0. pmid: 33798499

6 Ferguson J, Dunn S, Best A, etal. Validation testing to determine the sensitivity of lateral flow testing for asymptomatic SARS-CoV-2 detection in low prevalence settings: Testing frequency and public health messaging is key. PLoS Biol 2021;19:e3001216. doi: 10.1371/journal.pbio.3001216. pmid: 33914730

7 Torjesen I. NHS Test and Trace: lack of progress is "deeply disappointing". BMJ 2021;373:n1636. doi: 10.1136/bmj.n1636 pmid: 34167940

This article is made freely available for use in accordance with BMJ's website terms and conditions for the duration of the covid-19 pandemic or until otherwise determined by BMJ. You may use, download and print the article for any lawful, non-commercial purpose (including text and data mining) provided that all copyright notices and trade marks are retained. 